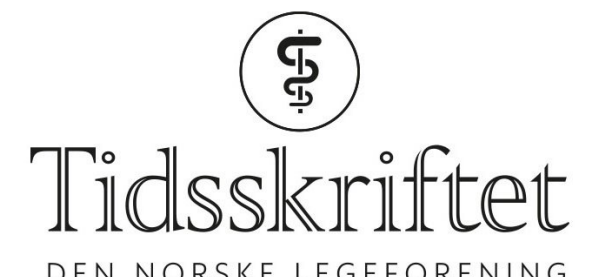

DEN NORSKE LEGEFORENING

\title{
Medisinen mellom linjene
}

ESSAY

\section{KETIL SLAGSTAD}

E-post: ketil.slagstad@legeforeningen.no

Ketil Slagstad er lege og medisinsk redaktør i Tidsskriftet.

Forfatter har fylt ut ICMJE-skjemaet og oppgir ingen interessekonflikter.

Border, skriblerier, utgulinger, fotnoter, innholdsfortegnelser, fonter, illustrasjoner, kommentarfelt og design er også medisin.

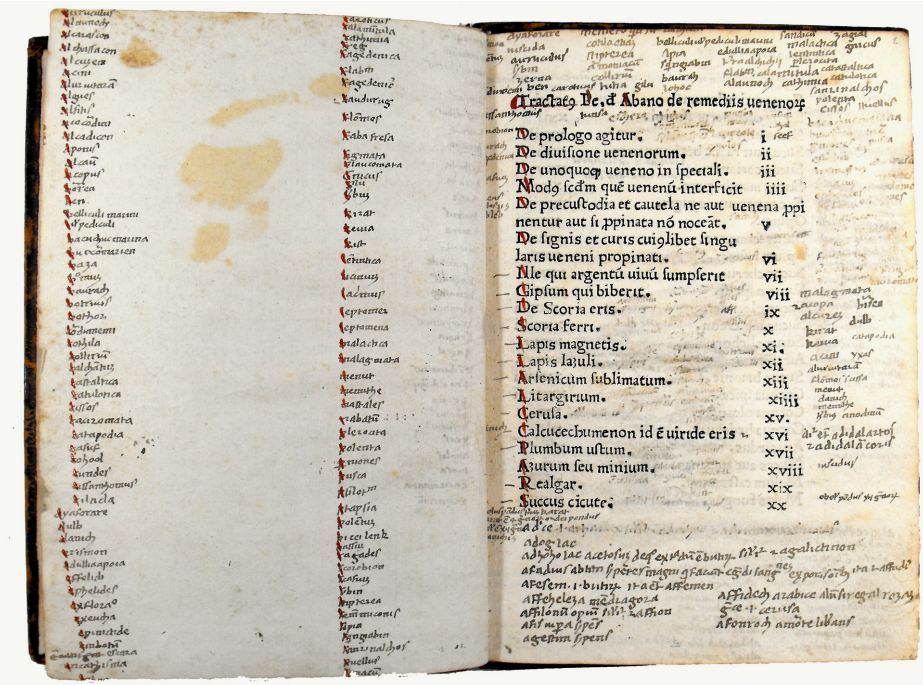

Petrus de Abano (1257-1316) var en italiensk filosof og professor i medisin. I boka De venenis som er basert på arabiske kilder, og som blant annet omhandler gifter, er medisinske tilstander og medisinalplanter sirlig ordnet kolonnevis med tilhørende notater og annotasjoner. Robert MacLean argumenterer for at disse tekstene ble skrevet for ettertiden, $i$ datidens paniske ambisjon om å bevare «alt». Derfor ble også de tilføyde notatene rubrisert og ordnet med kapitaliserte forbokstaver i rødt for å ordne informasjonen for senere generasjoner. Illustrasjon: Petri de Abano. De venenis. Roma: Georgius Sachsel and Bartholomaeus Golsch, ca. 1475. Gjengitt etter tillatelse fra University of Glasgow Library, Special Collections.

Å lese en gammel bok full av understrekninger og skriblerier kan være irriterende. Samtidig kan border, margnotater, tegninger, bilder og utgulinger gi en tilgang til historien som vi kanskje ikke har vært tilstrekkelig oppmerksom på, i hvert fall innen medisinsk historie. Denne påstanden er utgangspunktet for antologien Medical Paratexts from Medieval to Modern om et relativt nytt forskningsfelt, nemlig medisinsk paratekst eller ikke-tekstlig medisinsk tekst.

Boken innledes med at redaktørene Hannah C. Tweed og Diane G. Scott omtaler det 
mystiske tilfellet Mary Toft, som i 1726 fødte ni kaniner, bevitnet av en britisk kirurg. Tilfellet medførte stor pressedekning og fikk sagnomsust karakter blant annet fordi det figurerte i sketsjer og ballader. Etter at Toft gjennomgikk gjentatte bevitnede kaninfødsler ble hun brakt til London for å bli grundig undersøkt av kirurger, medisinere og mannlige jordmødre. Det ble der avslørt at ektemannen hadde forsynt henne med døde kaniner som hun hadde benyttet under «fødslene». Etter å ha blitt truet med tvunget keisersnitt tilsto hun udåden.

Hvilken rolle spiller Tofts historie i en bok om medisinens paratekst? Avsløringen medførte et skred av innlegg fra blant annet leger, kirurger og jordmødre, og redaktørene argumenterer for at debatten, med all den tekst som ble produsert, bedre kan forstås om vi analyserer ikke bare tekstene selv, men også deres paratekst. Paratekst defineres og avgrenses ulikt, og i bredeste forstand omfatter det alt rundt hovedteksten som selv formidler informasjon og mening (para betyr «ved siden av» på gresk). Parateksten omfatter periteksten - for eksempel illustrasjoner, omslag, kolofon, annotasjoner i margen, overskrifter, noteapparat - altså det som er knyttet til selve hovedteksten, men som selv ikke er del av den. Paratekst omfatter også epiteksten, dvs. tekst produsert utenfor den opprinnelige teksten, slik som litteraturanmeldelser, tilsvar, korrespondanser, offentlige debatter, pressemeldinger. Epiteksten forteller oss om de sosiale, politiske og kulturelle faktorene som formet tekstproduksjonen.

Et viktig poeng som redaktørene understreker, er at paratekst alltid medierer mellom forfatter, forlegger og leser: paratekst er relasjonell. I Tofts tilfelle demonstrerer en slik paratekstanalyse hvordan kvinnekroppen ble objekt i en kamp der mange hadde behov for å forsvare sin kunnskap og profesjon, ikke minst siden så mange fagfolk hadde blitt ført bak lyset. Analysen viser også hvordan nye muligheter for publisering i det 18. århundret ble tatt i bruk av en stadig mer selvsikker legeprofesjon.

\section{Medisinsk-erotisk kunnskap}

Boken inneholder ni kapitler i tillegg til introduksjonskapitlet, og de fleste forfatterne har bakgrunn fra historie, litteratur- og språkfag. Spennvidden er stor: tidsmessig fra det 14. århundret til det 21., og temamessig fra illustrerte flyveblad fra det 17. århundret som reklamerte for kvakksalveres kirurgiske inngrep, til sykepleieres oversette dagboknotater fra første verdenskrig. Dette vitner igjen om forfattere som selvbevisst sjonglerer mellom ulike roller - feminister, profesjonelle, øyevitner, historikere. En slik perspektivbredde gir tyngde til argumentet om paratekstens betydning for historieskrivning. På den annen side er det fare for at argumentet kan bryte sammen dersom eksemplene ikke oppleves å være relaterte. Redaktørene har klart å balansere disse hensynene godt.

Fire kapitler vakte særlig interesse hos denne leseren. Harry Newman demonstrerer overbevisende hvordan trykte kilder ikke bare er passive objekter, men aktører både i tiden de ble skrevet og i påfølgende generasjoner. Det viser han ved å undersøke anatomiverket Mikrokosmographia: A Description of the Body of Man utgitt i England i 1615. Gjennom bokens inskripsjoner finner Newman indikasjoner på at bøkene ikke bare ble lest av lærde, men også av vanlige folk og at de var eid og ble lest av både kvinner og menn. Særlig illustrasjoner av kvinners anatomi skapte debatt i medisinske kretser og ble funnet usømmelige. I påfølgende utgaver ble den lille streken i vulva, som hadde visualisert spalten mellom kjønnsleppene, fjernet. Det medførte, ifølge Newman, et påfallende nærvær av det fraværende (fig 1 ). Nettopp ved å fjerne/sladde/retusjere det vovete ble det forbudte fetisjert. Ved å analysere bøkenes paratekst av både advarende («det som kommer kan virke støtende») og unnskyldende karakter («hvorfor er det viktig å publisere dette?»), demonstreres en medisinsk-erotisk kunnskap og de medisinske paratekstenes fetisjistiske funksjon. 


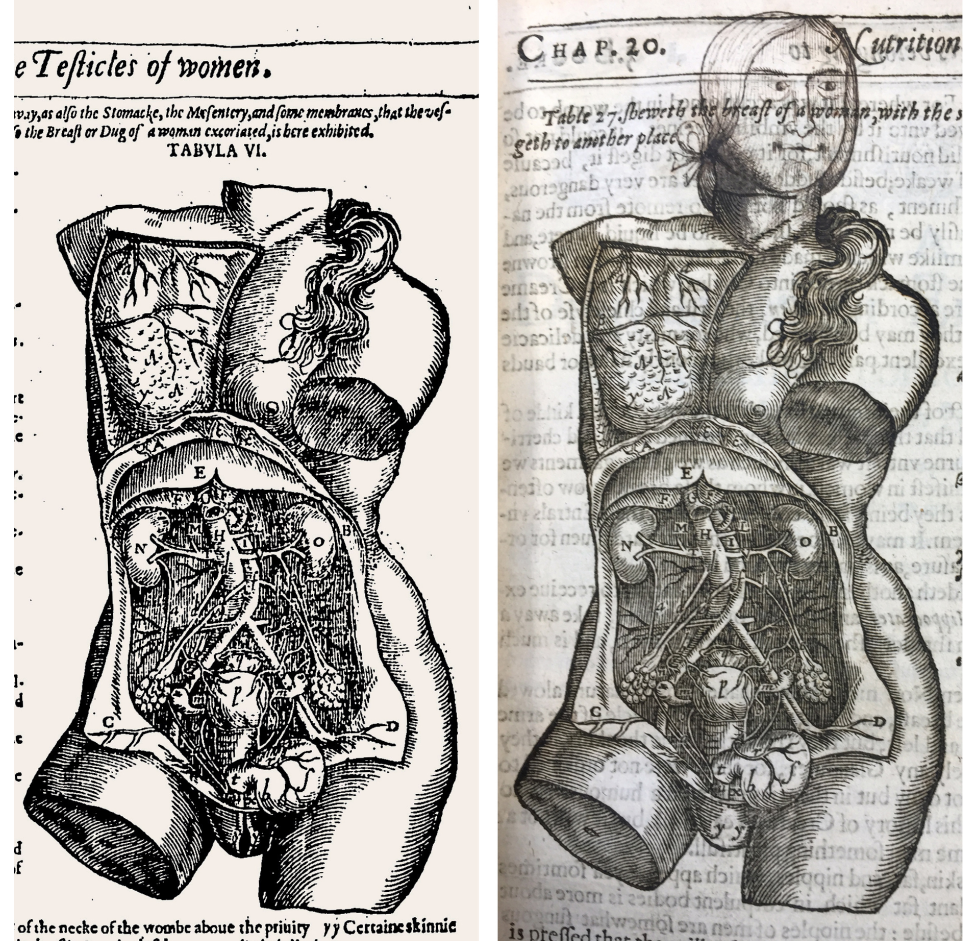

Figur 1 Figuren viser en kvinnelig torso i to forskjellige utgaver av boken Mikrokosmographia: A Description of the Body of Man av Helkiah Crooke. Til venstre er originalutgaven utgitt 1615, til høyre utgaven fra 1631 der spalten mellom kjønnsleppene har blitt sensurert bort. I andre versjoner har lesere tegnet vulvaspalten inn på nytt. På illustrasjonen til høyre fra 1631-utgaven har en leser påtegnet et hode i penn. Sensureringen, avsensureringen og personaliseringen av torsoen er eksempler på at parateksten synliggjør et historisk forhold mellom forfatter, utgiver og leser. Illustrasjon til venstre: Helkiah Crooke. Mikrokosmographia, 1615. Reel position: STC/1409:01. Henry E. Huntington Library and Art Gallery. Gjengitt etter tillatelse fra ProQuest Early English Books Online, må ikke gjengis uten tillatelse. Illustrasjon til høyre: Foto ved Robert MacLean. Gjengitt etter tillatelse fra University of Glasgow Library, Special Collections.

\section{Tvillingberørelse: ubehaget i kulturen}

I et annet kapittel unders $\varnothing$ ker Louise Powell samspillet mellom tekst og bilder i to engelske jordmorbøker fra det 17. århundret. I datidens fødselslære var berøring ansett som et viktig diagnostisk hjelpemiddel. Ved å palpere kunne jordmor identifisere tvillingsvangerskap som ga seg til kjenne ved en sagittal kløft over mors buk. Slik kunne sammenvokste tvillinger, som ble ansett som «monstrøse svangerskap», skilles fra vanlige tvillinger. Det premisset hvilte imidlertid på tanken om at det kun var interaksjon mellom tvilling og mor (og mellom sammenvokste tvillinger), men ikke mellom vanlige tvillinger selv. Slik kunne berøringspraksisen som diagnostisk verktøy uproblematisk forsvares i læreboktekstene, men Powell fremhever at illustrasjonene samtidig fortalte en annen, mer kompleks historie. For her holder tvillingene fast i både hverandres armer og ben (fig 2). Samspillet mellom tekst og paratekst formidler en nervøs dobbelthet: På den ene siden berører tvillinger hverandre ikke og kan derfor diagnostiseres utenfra (tekst), på den annen side berører de hverandre og formidler derigjennom at de innehar et spesielt bånd (illustrasjoner/paratekst). Powell finner begrunnelsen for tekstbøkenes doble budskap i datidens utbredte praksis med å skille tvillingene fra hverandre etter fødsel. Siden det var antatt at mor ikke ville ha nok melk til begge, beholdt mor kun én. Den andre ble gitt til en amme. Samspillet mellom tekst og bilde formidler at denne praksisen innebar et visst kulturelt ubehag, samtidig som atskillelsespraksisen kunne forsvares: Ja, tvillinger har et spesielt bånd, men det er sterkt nok til å tåle separasjonen etter fødselen. 


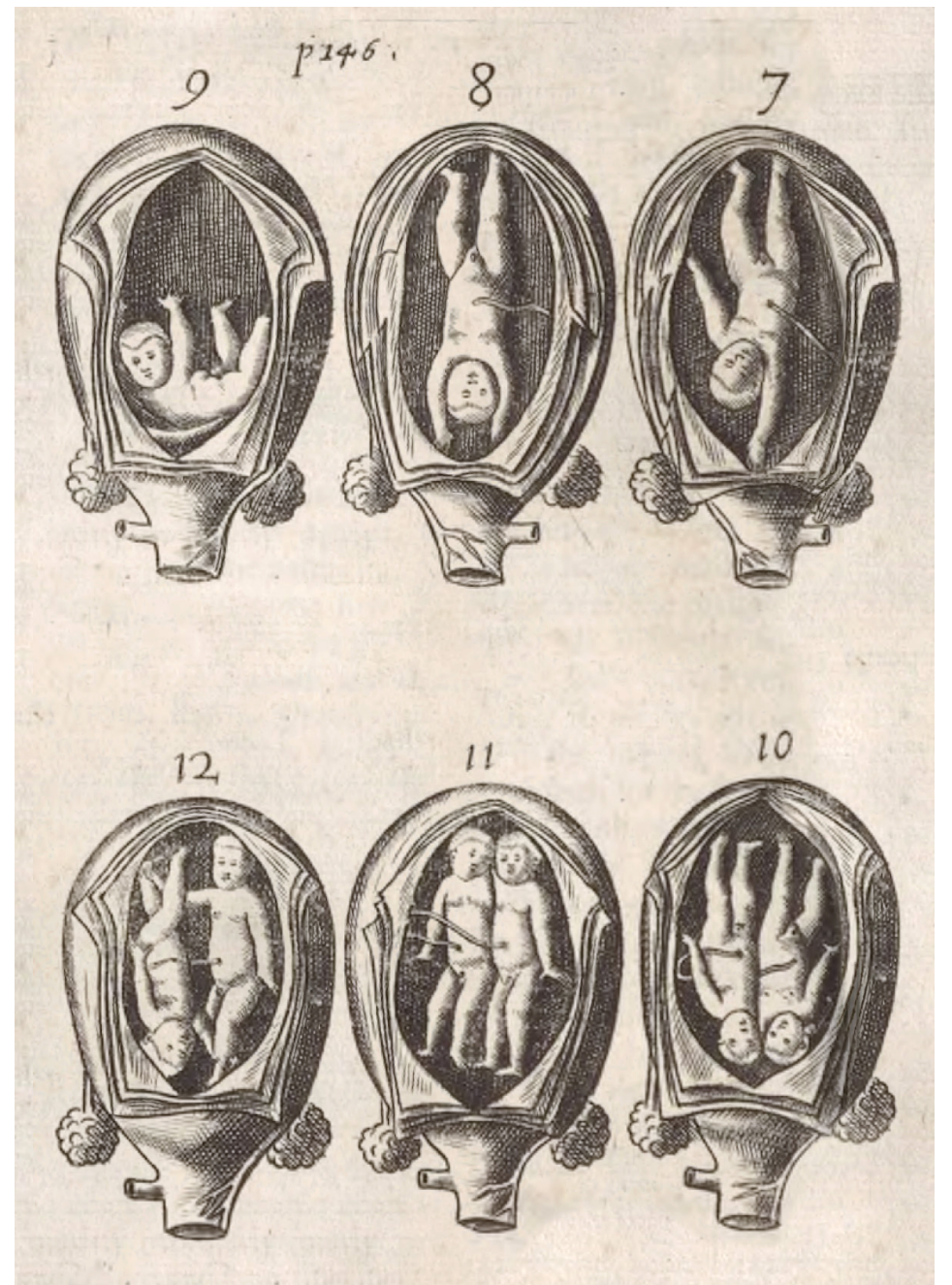

Figur 2 Tvillinger in utero $i$ Thomas Chamberlaynes bok for jordmødre, The Compleat Midwife's Practice Enlarged fra 1656. Mens det i teksten ble fremholdt at tvillingene ikke berørte hverandre, ble tvillingene på illustrasjonene vist å holde fast $i$ hverandres armer og ben. Denne dobbeltheten formidlet et ubehag $i$ samtiden ved praksisen om å skille tvillinger etter fødselen. Foto: Thomas Chamberlaynes. The Compleat Midvife's Practice Enlarged, London:J.P. Fellow of the College of Physicians, 1697. Fritt tilgjengelig ved U.S. National Library of Medicine. Digital Collections.

\section{Paratekst og medisinens kredibilitet}

Laura Mainwaring analyserer hvordan emballasje og reklame for farmasøytiske produkter sier noe om paratekstens innvirkning på det medisinske markedet med legemiddelprodusent, apotek og konsument i overgangen fra det 19. til det 20. århundret. Patenterte medisiner var noen av de første produktene som ble distribuert på nasjonalt plan, allerede fra det 17. århundret, og legemidler har derfor spilt en tidlig rolle i reklamens historie. En vesentlig formalisering av varemerker skjedde ved den britiske loven Trade Marks Registration Act of 1875, som definerte et varemerke som et visuelt kjennetegn eller logo. Det medførte at legemiddelemballasje og -reklame ble merket med typografisk tekst eller logoer som tydelig signaliserte et bestemt varemerke. Mainwaring leser produktene og reklamens paratekst som uttrykk for et behov for å demonstrere autentisitet og troverdighet i et i økende grad depersonalisert kapitalistisk marked, der direkte relasjoner mellom produsent og forbruker var brutt, for eksempel gjennom apotekene (fig 3 ).

Parateksten demonstrerer derfor, mener Mainwaring, at produsentene hadde større tillit til forbrukernes vurderingsevne når det kom til legemidler enn hva som tidligere har vært antatt. Paratekstens materialitet (f.eks. legemiddelflasker, varemerkestempler, forsiktighetsdeklarasjoner, forpakninger og reklame) forteller derfor to historier. For det første sier den noe om hvordan legemidler har blitt kommunisert til befolkningen gjennom historien. For det andre demonstrerer den hvordan legemidlene ved overgangen 
til det 2o. århundret hadde fått nye funksjoner og i økende grad henvendte seg direkte til forbrukeren. Parateksten pekte derfor fremover mot et århundre der legemidler og medisinen så til de grader skulle komme til å spille en dominerende rolle i samfunnsutviklingen og menneskers liv.

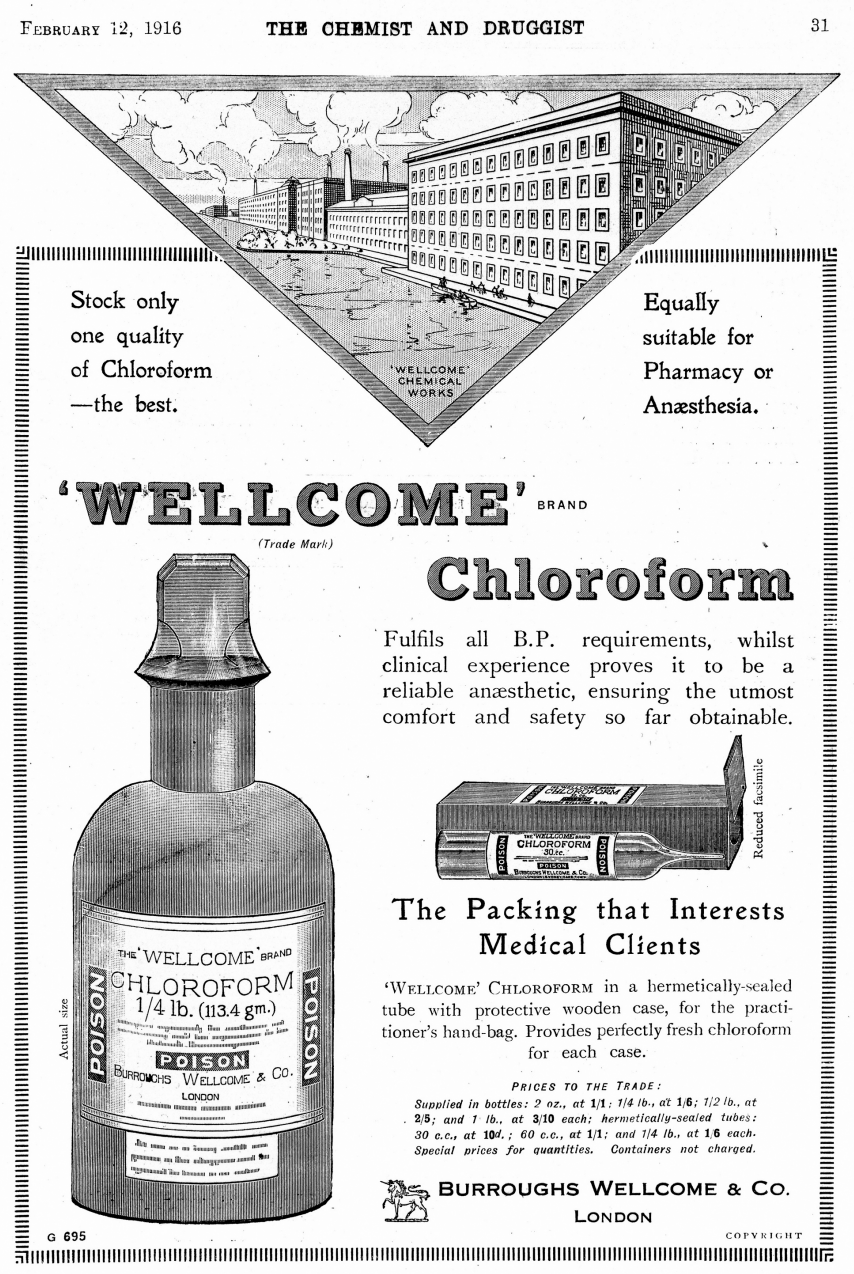

Figur 3 The Chemist and Druggist var et magasin rettet mot salg av legemidler til apotek. Parateksten i denne Wellcome Brand-reklamen fra 1916 for bedøvelsesmidlet kloroform kommuniserte flere budskap: en selvbevisst farmasøytisk industri på fremmarsj (monumentale industribygninger $i$ moderne nyklassisistisk stil), en paranoia for forfalskninger (flaske i naturtro størrelse, forpakning og forsegling) og et varemerke (Wellcome brand, Trade Mark). Foto: Wellcome Collection.

I det siste kapitlet tar Robert MacLean oss med på en svipptur gjennom annotasjoner, skriblerier og indekseringer i tekstbøkers marg - såkalt marginalia - i et utvalg medisinske inkunabler (bøker trykt med gammel trykkekunst før år 1500) og trykkilder om syfilis fra perioden 16.-18. århundre. Et av MacLeans poeng er at katalogisering og arkivering av slike metadatarike kilder er svært tidkrevende og koster mye penger. Kun en brøkdel av tidlige trykte kilder har blitt katalogisert på et tilstrekkelig detaljert nivå, som igjen representerer en betydelig begrensning for forskning på medisinsk marginalia.

\section{Historien som blir}

Samlet sett utvider boken vår forståelse av medisin som papirteknologi. Ikke bare ser vi hvordan medisin i stor grad har handlet om å skrive for samtid og ettertid, men også hvordan samtidens tekst har fortsatt å virke i ettertiden. Boken leverer et godt argument for at om vi tillegger parateksten kanskje like stor vekt som selve teksten - og tar med illustrasjoner, fonter, innholdsfortegnelser og fotnoter, publiseringsformat, tegninger og notater i margen, mottagelse, korrespondanser og brev - kan det åpne opp for nye perspektiver på tekstenes dialogiske, aktive og historiske funksjoner. 


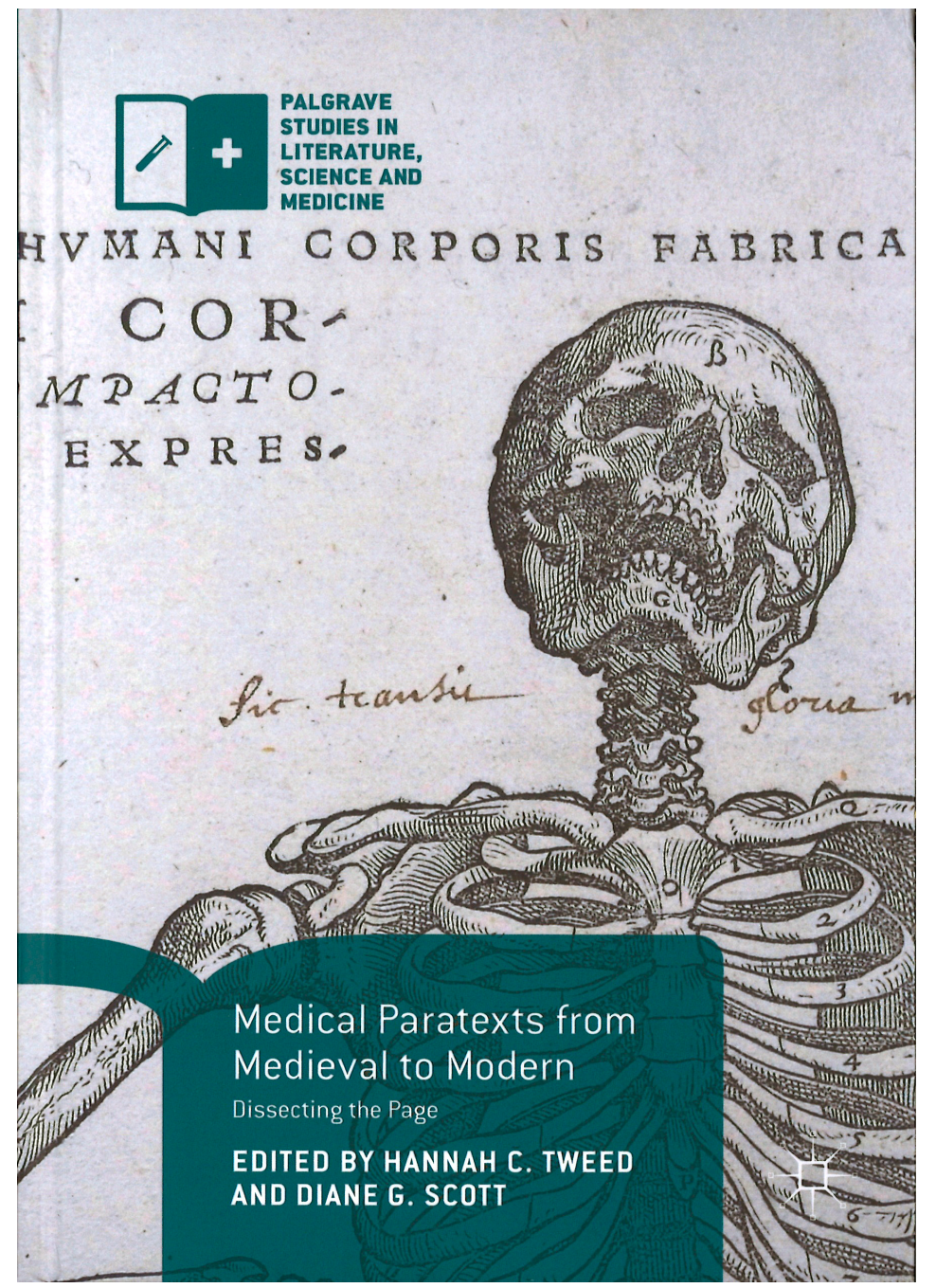

Aktuell bok. Hannah C. Tweed, Diane G. Scott, red. Medical paratexts from medieval to modern. Dissecting the page. London: Palgrave Macmillan, 2018.

Men paratekst er ikke bare et fenomen i historiske tekster. Tidsskriftet der denne artikkelen er publisert, er fullt av paratekst som (kanskje) fremtidens historikere vil analysere for å forstå medisinen rundt starten av det 21. århundret: Vi inviterer kunstnere til å illustrere forsiden for å gi andre blikk på original forskning, kommentarfeltene gjør at artikler trykt på papir får nytt liv på nett, og nye artikkelsjangertyper skal gjøre det lettere for oss å organisere kunnskapen.

Et av historikerens kraftigste og viktigste virkemidler er kontekstualisering - dvs. å plassere en tekst, et arkivmateriale, et objekt, i sin tid og forstå den på datidens premisser. Med det trekkes andre tekster, andre diskurser, sosiale, politiske og kulturelle forhold inn for å forstå sammenhengen teksten ble skrevet i. Men kontekstualisering har også blitt kritisert for å være en «lettvint» måte å forklare noe historisk som man ikke har undersøkt nok i detalj (1). Historien blir en «svart boks» hvor fortiden bare er, atskilt og uten referanse til nåtiden, og hvor historikerens oppgave bare er å finne ut av hvordan «ting egentlig var».

Men historie er også noe man gjør; historien er noe som blir til (2). Tekster er ikke bare passive representasjoner av svunnen tid. De agerte på tidspunktet de ble skrevet, de ble brukt i generasjoner etterpå og de fortsetter å virke i nåtiden i vår forståelse av fortid, nåtid og fremtid. Det er nettopp dette poenget jeg synes kommer tydelig frem i denne lille, men nydelige antologien, der tidens spor får figur. Kontekst er latin for «å veve sammen». Tekster reiser på tvers av og vever sammen tid. Retter vi øynene mot parateksten, blir tiden og situasjonen teksten oppsto og virket i litt mindre passiv og litt mer levende. Det gjør at vi kan forstå fortidens medisin litt bedre - og kanskje også få noen nye perspektiver på egen praksis. 
LITTERATUR:

1. Felski R. Context Stinks! New Lit Hist 2011; 42: 573 - 91. [CrossRef]

2. Asdal K, Jordheim H. Texts on the move: textuality and historicity revisited. Hist Theory 2018; 57:56 74. [CrossRef]

Publisert: 26. november 2018. Tidsskr Nor Legeforen. DOI: 10.4045/tidsskr.18.0631

Mottatt 9.8.2018, godkjent 19.9.2018.

(C) Tidsskrift for Den norske legeforening 2020. Lastet ned fra tidsskriftet.no 